\title{
Study on Power Centers in Iran: Continuum of Political, Social and Economic Power as a Framework for Discipline Analysis
}

\author{
Abdollah Rasekhi, Javid Mohammadi \\ Department of Law and Political Science, Takestan Branch, Islamic Azad University, Takestan, Iran \\ Email: rasekhi1352iran@gmail.com
}

Received 26 November 2015; accepted 3 April 2016; published 6 April 2016

Copyright @ 2016 by authors and Scientific Research Publishing Inc.

This work is licensed under the Creative Commons Attribution International License (CC BY).

http://creativecommons.org/licenses/by/4.0/

\begin{abstract}
This article studies power organizations and their role in political, social and economic discipline in Iran. Religion, tradition and organizations are the sources of political and social power in Iran. Water, land, oil and mining are economic power resources. The economy is governmental, and power is personal and organizational. The supreme leader and the legislature of view of the decisions and the executive of view of the administration have the top position in power trend. Islamic republic system is relying on supreme leader, so that the authority's adjusting actions are in accordance with his perspectives. In this article, the information is analyzed using the systems theory. In this theory, the interrelationship of power centers and their role in policymaking process, the effects of domestic and international environments on decision making, and importance of organizations function in support of the system are studied.
\end{abstract}

\section{Keywords}

Power Centers, Supreme Leader, the Legislature, the Executive, NGOs, General Economic Organizations

\section{Introduction}

Power literally means the ability to force others to do something they do not want to (Dahl, 1957: p. 67). Power, in its specific sense, is a social relation through which a common interest is obtained. Power usually refers to the relations between individuals and groups. In social systems, power entails the reproduced relations between independence and dependence in social interactions. Power is developed in institutions. Traditions, customs, legal 
structures, and common methods influence the formation of institutions. Institutions have certain rules, hierarchical and personal structures, and relative independence in their performance. Power has numerous centers and is located in organizations. The formation of power centers is influenced by such factors as political, social and economic structures, geographical conditions, historical experiences, and ideology, the relation between religion and politics, and traditional or modern shape of society. The question that comes to mind in this research is the following: Centers of power in Iran includes whether personalities or organizations have a role in the decision making and executive. Obviously, Iran's politics and economy are two interconnected components which influence the culture.

In order to understand the power centers in Iran more perfectly, this article will examine the power centers according to political, social and economic functions generally, as well as personal and organizational power. The article will arrange the analysis in framework of systems theory. By applying this cognition, power centers are in three forms of organizations functions, rational-scientific pathologies for political, social and economic continuum of power centers. This study will analyze the insights to the thinkers in order to offer suggestions for nullifying challenges and creating more opportunities.

\section{Theory of Systems}

Any social phenomenon can be regarded as one or more interrelated systems. The components with more cohesion and correlation are considered as a system. These components which are conceptually measurable are called variable. The variables of a system may be structures, acts, actors, values, norms, goals, inputs, outputs, responses and feedbacks.

Robert Lilienfeld (1975) refers to biology, cybernetics, and operation research. Cybernetics is the orderly study of communications and control in any organizational type. W. Ross Ashby (1956) suggests that individuals and societies act based on cybernetics theory and human behavior can be illustrated by a set of variables. In sociology, Jantsch (1972) refers to human thought systematic conduction methods and deals with a foresighted framework for strategic planning (Jantsch, 1972: pp. 482-484). Merriam (1966), with a belief in evolutionary nature of effort and political success, suggests that the whole process of life, including the governance and politics, is a part of creative evolution through which the human and his values promote permanently (Merriam, 1966: p. 74).

Easton (1953) believes that political system should be considered as a whole unit. He refers to psychological and situational information. The former relates to the personality and motives of actors and the latter relates to the impact of environment on the activity of actors (Easton, 1953: p. 78). Political system is identified by the actions relating to binding decisions in a society. Political actions constitute the units of political system. Inputs enter political system in the form of demands and supports. Demands arise from the environment or from inside the system and resemble the issues which political system members attempt to address through identified channels of the system. Supports are actions or orientations which play a motivational or deterrent role for the political system. Outputs exit the political system in the form of decisions and actions. If outputs meet the demands of certain members of the system, these members support the system. But outputs may have negative consequences as well, in which case the system faces new demands (Easton, 1957: pp. 389-390). Society as a supra-system is the most comprehensive social system. Therefore, political system is a set of interactions separated from the whole social behavior which deals with allocation of values in the society. Political life is an open system which is influenced by surrounding environment. Environment includes intra-social and extra-social environments. Ecological (physical), biological (human genetics), and personality and social (cultural, population and economic) systems are parts of the intra-social environment which are important to political system. International environment is made up of international ecological systems, international social systems, and international political systems. National political systems, the United Nations, and North Atlantic Covenant are some examples of international political systems (Easton, 1965: pp. 57, 73).

The pressures exerted to change a system include internal pressures from intra-social environment and external pressures from extra-social environment. Easton refers to the concept of performance and suggests that decision making is one of the components of political analysis framework. Spiro (1962) believes that a society which solves the problems is a political system. Problems are detected and eliminated during the flow of policy. In his opinion, the process of policy includes formulation, deliberation, resolution and solution. Spiro believes that the process of policy is connected with the issues relating to constitution, economy, power and culture and success or defeat of this process depends on stability, flexibility, efficiency and effectiveness (Spiro, 1962: p. 
580).

In cybernetic model, Deutsch (1963) refers to the concepts of self-controlling system, memory, recognition, feedback and balance. He believes that the policy is the conduction of human behavior, so policy can be shaped by means of major communication facilities, memory and other instruments. According to Deutsch, there are four types of political system: self-destroying systems, which are usually destroyed against the environment; nonviable systems which have problems surviving in the environment; viable systems which can possibly survive against the environment; and self-developing systems which can possibly survive more than other systems (Deutsch, 1963: pp. 243, 249).

\section{Power Centers in Iran}

\subsection{Political Power Centers}

A) Political Organizations Affiliated with the Supreme Leader: this organizations including the Expediency Council, Broadcasting and the Islamic Revolutionary Guard's Corps. The Expediency Council has such duties as making decision about the resolutions passed in the Islamic Consultative Assembly and the Guardian Council, preparation and proposing the draft of major policies, solving problems in the system, making decision regarding interpretations, giving consultation to the Supreme Leader, investigation of the affairs relating to the Supreme Leader in the case of his decease, resignation or dismissal, and participation in constitution revision council. The Expediency Council consists of a group of major authorities of the country who are experienced in various fields. Since the Supreme Leader is elected by people through the Elites Assembly, he appoints some persons from different political and social groups to meet the demands of people. This encourages public participation and contributes to the political legitimacy and democracy. Major policies of the system shall be confirmed by the Supreme Leader after being investigated in the Expediency Council. The actions taken by the three powers are within this framework and the change of parliament period and government does not make a major change in the main policies of the country. Likewise, global and regional cooperation are fixed within the same framework.

The Broadcasting is the only official media power center in the country which represents the ideology, policies and actions of the sovereignty. It is the only center for broadcasting radio and TV programs which is under supervision of the Supreme Leader. Moreover, a board composed of the President; head of the Judiciary and Islamic Consultative Assembly supervise the broadcasting. Being an independent organization not influenced by political trends, the Broadcasting plays an important role in the promotion of public awareness, exchange of views, enhancement of public culture, filling leisure times, and protection of the national unity and integration. This organization can investigate and criticize the performance of the Executive. That how much the Broadcasting has managed to influence the people should be investigated. In order to enhance the materials, increase public satisfaction and meet the demands of people, the representatives of different groups of the society should be present in the Broadcasting.

The Islamic revolutionary Guards Corps the duty of protecting the achievements of the Islamic Revolution and strengthening the defense power of the country. It is the center of military force and has two functions: fighting against those who conduct military attack against the Islamic Republic of Iran and fighting against those who seek to change the system. The army fights against territory threats and the Islamic Revolutionary Guards Corps against internal threats. The Islamic Revolutionary Guards Corps has the duty of forming public forces mobilization, protecting the safety of Supreme Leader, political characters and nuclear scientists, and protecting the airports. The Islamic Revolutionary Guards Corps in political domain, as an influential group.

B) The Legislature: The legislature is composed of two fully distinct components of the Guardian Council and Islamic Consultative Assembly. The Guardian Council consists of six faqihs and six jurists. Faqihs are elected by the Supreme Leader and jurists are elected by the head of the Judiciary and both are introduced to the Islamic Consultative Assembly. The faqihs of the Guardian Council have an effective role in the elections and political trends of the country through comparing the laws with the constitution and religious fundamentals. The Guardian council has full power to supervise the Presidential Elections, Elites Assembly Elections, and Islamic Consultative Assembly Election, and its decisions about the qualification or disqualification of candidates are binding and final. Among the decisions made by the Guardian Council regarding the qualification of candidates is about the requirements of management, wisdom, trustfulness, belief in God, belief in the Islamic Republic of Iran for president, scientific qualification for Elites Council, practical belief and practical commitment of Par- 
liament members in Islam, Islamic Republic, and leadership of faqih. Moreover, the legislations of Islamic Consultative Assembly are valid only if confirmed by the Guardian Council.

Islamic Consultative Assembly is a combination of representation, discussion and negotiation, legislation and supervision, and injects the demands of different social layers into the system. While being the representatives of their respective domains, Parliament members make policies and planning for the entire country. Islamic Consultative Assembly also has the power to exercise financial and political supervision. The Legislature's right to supervise the Executive encourages Parliament members to unlimitedly interfere in their respective domains. Some members even interfere in minor affairs such as appointments and dismissals and exert pressure on the minister under the pretext of defending public interests. This occurs while according to article 174 of the Constitution, supervision over administrative affairs of ministries is the responsibility of the Judiciary and shall be executed through State Inspection Organization and Administrative Justice Court. While the Islamic Consultative Assembly can supervise the tasks of ministers, the Executive may influence the Islamic Consultative Assembly using financial and political tools.

C) The Executive and Subsidiary Organizations: The executive is a semi-presidential or semi-parliamentary system. It is presided over by the President who is the highest authority of the country after the Supreme Leader. As the President earns his votes directly from people, he has the responsibility to meet their demands and request. The President also has the financial responsibility of the country through his colleagues. Executive protection of the constitution is the responsibility of the President, which is fulfilled through supervision and inspection. Legislative protection of the constitution is the responsibility of the Guardian Council, which is performed through supervision over ratifications of the Islamic Consultative Assembly.

Organizations which have political power under supervision of the President include National Security Supreme Council, and Martyr and War Veterans Foundation. National Security Supreme Council has been founded with the aim of protecting national interests, the Islamic revolution, territorial integrity and national sovereignty. The Council makes laws in the field of national security in line with the goals of Islamic Consultative Assembly. The members of National Security Supreme Council consist of political, military and security institutions. The Council is a combination of official, unofficial, elected and appointive institutions. Its members are the main power centers in the country. The most important actions taken by National Security Supreme Council is the investigation of issues relating to the imposed war between Iran and Iraq, such as the Resolution 598 of the UN, the issues concerning captives, issues of nuclear country, and Resolution 2231 of the UN.

Martyr and War Veterans Foundation is a revolutionary and governmental institution which deals with the issues relating to families of 220,000 martyrs, 505,000 war veterans, and 50,000 released captives. This Foundation is one of the legitimacy arms of the Islamic Republic of Iran. It reproduces the loyalty to the system through distribution of financial resources, payment of educational expenses, creation of occupational opportunities, and provision of marriage facilities to the survivors of martyrs and war veterans. As the families of martyrs and war veterans are among the influential groups in the country, politicians and authorities have always paid special attention to this foundation.

D) NGOs: Intermediate institutions and Islamic councils are examples of NGOs. The individuals in intermediate institutions, including groups, associations, communities, union, religious councils, art society, sport clubs, cooperatives and charity organizations, discuss the future of the society, analyze the issues relating to the society, and provide solutions for the problems. They also influence the decision adopted for the public affairs. Intermediate institutions can correspond and meet with Parliament members and the cabinet ministers in order to request for modification of policies. These institutions express their wishes through forming the gatherings, declaring their requests and publishing their ideas. Intermediate institutions also establish liaison with the system whereby influencing the decisions and policies. These institutions fall under the domain of civil society, act as an intermediary between people and government, and are the most important means of achieving democracy. They pursue collective and individual activities and show some inclinations towards the management of political and economic affairs. These institutions are active in the management of society, such as Islamic Council and Islamic Consultative Assembly. The religious councils pay to national celebrations and mourning ceremonies at mosques and religious site. These councils have the individuals that they are responsible mainly and have tribune. They have many fans. Religious councils have two approaches: religious approach and religious-political approach. The councils with religious-political approach are greatly influential in the society. That is why political characters approach and interact with the religious councils. After the Islamic Revolution, there has always been an interaction between the religious councils, market and the government. 
Interests, needs and dependences have encouraged people to participate in social affairs by founding the Islamic Council. This Council is most familiar institution with local situations and conditions and greatly contributes to reproduction, control and supervision of system. The formation of Islamic Council of urban and rural areas indicates the just distribution of power in religious and democratic society of Iran. In the elections of Islamic Council in rural areas, ethnic issues are more influential. Islamic councils in urban areas are elected by people and are granted authorization from the ministry of interior. In other words, they are the representatives of people and government authorities. The investigation about the performance of city Islamic council indicates that the arrival of these councils into the arena of political conflicts of the rival groups and intervention of Islamic Consultative Assembly in city affairs, particularly major cities, is an indication of existing deadlocks in the evolution of current urban management system. In addition, the presence of ambiguous laws and centralized bureaucracy has led to the inefficiency of city Islamic council and restriction of their powers and authorities. In such situation, the power has actually been centralized in the hand of the government rather than being distributed in city Islamic council and municipality. To solve this problem, various political groups should help the city Islamic council and municipality in the performance of their duties and private and public sectors should cooperate in urban affairs.

\subsection{Social Power Centers}

A) Cultural Revolution Supreme Council: This council is a revolutionary institution presided over by the President. It adopts decisions in major level in cultural, educational, research and media fields. The council also prepares and codifies country comprehensive scientific map, determines the criteria for cultural centers and the terms for election of professors and instructors, specifies the priority for the budget of five-year programs and annual budgets in the said domains, and approves cultural attachments of national, economic, civil and industrial programs. Cultural Revolution Supreme Council is one of the main components of the system when it from system. Cultural Revolution Supreme Council guides and supervises cultural institutions. To be more efficient, the Council should pursue major operations through fundamental planning.

B) Culture and Islamic Communication Organization: The representatives of this organization reflect the achievements of the Islamic Republic of Iran and interact with other religions abroad. This organization also introduces cultural affiliates in the embassies to the ministry of foreign affairs, so that they are entrusted with ideological justification of the system abroad and promotion of Islamic teachings. Generally speaking, this organization reproduces cultural penetration of the system outside of the country.

C) The Seminary: A part of clergies are actively present in marriage and divorce registries, public and family courts, Islamic Culture and Communication Organization, Islamic promotion Organization and Pilgrimage and Endowment Organization. The clergies not only receive great support from the system but also are religiously supported by guilds and agriculture sector. This public support stems from Islamic beliefs and values in the society. Owing to religious authority, the clergies enjoy the greatest social power and strong cohesion of within organization. They also have a set of communication tools and mechanisms such as mosques net-pulpits, preachers and religious representatives—and modern communication media—press and internet.

\subsection{Economic Power Centers}

A) Economic Organizations Affiliated with the Supreme Leader: these organizations include Islamic Revolution Guardian Corps, "Imam Khomeini” Command Execution Headquarters and Islamic Revolution "Mostazafan” Foundation. Islamic revolutionary Guards Corps includes “Khatam-ol-Anbia” construction Headquarters which pursues civil and economic activities such as dam making, road making, airport construction, reconstruction of installations in ports, and water and gas supply projects. Some criticize economic activities of the Islamic revolutionary Guards Corps believing that its activities should be limited to the protection of the Islamic revolution and defending its achievements. The arrival of Islamic revolutionary Guards Corps to economy arena may also lead to dissatisfaction of private sector, particularly conventional traders and businessmen. However, some believe that there is no limitation for economic activities of the Islamic revolutionary Guards Corps as it has logistic and engineering equipment. This institution enters economic activities when the private sector has no demand.

"Imam Khomeini" Command Execution Headquarters is a governmental institution which was founded in 1989 under the title of Imam's 8-Article Command Execution Headquarters by confiscating the belongings of 
"Pahlavi” Regime affiliates. This institution is active in the fields of construction, ICT, oil \& energy, industry and finance. Islamic Revolution "Mostazafan Foundation" has been established by the capital obtained from the confiscation of property and belongings of "Pahlavi Family" and their affiliates. This foundation is the biggest non-governmental actor in Iran's economy which not only pursues economic activities such as civil, tourism, agriculture, industry, mining, transportation and commerce, but also is active in the field of raw oil, vehicle importation, shipping, and financial services. This economic enterprise is one of the important economic centers of the system which acts for economic reproduction of the system. In other words, "Mostazafan Foundation" maintains the loyalty of war veterans and their families by providing them with educational and health services, residential units and job opportunities. Islamic Revolution "Mostazafan Foundation" is the means of applying authority, influence and redistribution of elite resources and is one of the components of economic and political power chain in the country. It is connected with influential social groups such as traditional marketers and advocates of the powerful bureaucrats.

B) Economic Organizations Affiliated with the Executive: Securities \& exchange organization and governmental banking network are two major economic organizations affiliated with the executive. The securities \& exchange organization is composed of the bourse of commodity, foreign currency and negotiable papers, investment funds, and holding companies. This organization seeks to supply sustainable financial resources of the government by reducing the dependence of government budget on oil income and investment in private sector. The improvement of securities \& exchange organization entails commodity bourse activities with the aim of increasing the scope of energy and agricultural goods transactions.

Governmental banking network constitutes around 15\% of the government's general budget. In this network, banks connect people to economic sector. Banks, particularly governmental ones, grant financial facilities to applicants in the time of natural disasters such as earthquake, flood and storm. They are also responsible for other public demands regarding financial facilities. In addition, banks create job opportunities for the people. Government has an effective role in the elections of board members and senior managers of banks through the central bank. Banking system is not responsible against investor's demands for LC. Banks manage enterprises rather than supporting production and industry. The reason might be the reduction of bank interest rate, tendency of banks towards brokerage activities, excessive support of banks from the government, bank sanctions from international financial system, and the weaknesses in bank system laws of the country. It should also be noted entrepreneurial activities of banks have had adverse economic consequences such as inflation recession, severe reduction of employment in production field, increased inflation, destruction of small enterprises and rent. Solving these problems entails modification and independence of banking system, increased supervision of central bank, and governmental support of banks.

C) Public Economic Organizations: Non-governmental financial organizations, supportive organizations, municipalities, and holy shrines are among public economic organizations. Non-governmental financial organizations mainly include private banks and financial and credit institutions. Private Banks have been established by investors, organizations and military forces. These banks make investment in the sectors of housing, stock exchange, oil \& gas, insurance and welfare complexes by using public capital and establishing affiliated companies. Financial and credit institutions possess are able to supply financial resources in return for pledge of assets and property and to do activity in insurance and investment fields. However, due to inequality between governmental and private banks in providing services such as bank service fees, earnings of different kinds of foreign currency transactions, and opening LC, these institutions have failed to play a significant role in the economy. Here it should be noted that some financial and credit institutions which are supported owners have established branches throughout the country without the permission of the central bank. Due to economic and social consequences, prevention of the activity of such institutions is actually impossible. The solution to this problem lies in revision of the regulations relating to establishment of banks and supervision of central banks over banks and financial institutions, collaboration of the Judiciary and Law Enforcement Force with the central banks, and competitiveness of money market.

Supportive organizations include Social Security Organization, consumer and producer protection organization, medical services organization, and retirement funds. Among supportive organizations, here we describe the function of "Panzdah-Khordad” Foundation, Imam Khomeini Relief Foundation, and Social Security Organization. "Panzdah-Khordad" Foundation is a non-profit organization which is active in the field of civil and culture. Imam Khomeini Relief Foundation is a non-profit financial institution which provides financial, educational and medical support to the families in need inside Iran and abroad. Hence the activities of this organization lead to 
support some vulnerable populations of system. This charity organization is highly dependent on governmental assistance. While this organization involves the government in its affairs, it makes the government vulnerable. It acts independent of the government and sometimes its programs conflict with governmental programs. The activity of this organization is similar to those of State Welfare Organization of Iran. Income resources of Social Security Organization include insurance premium, earnings from assets and investments, cash compensations, contributions and gifts. Social Security Investment Company is one of the most important subsidiary companies of Social Security Organization, whose affiliated companies are active in medicine, oil, gas, petrochemical, tile, rubber and paper industries. It could be said that Social Security Organization deals with economic and social security, satisfaction, and welfare of the people. The enthusiasm of some Parliaments members and governments for Social Security Investment Company is undeniable. In general, supportive organizations are somehow independent in terms of income recourses and are based on special incomes from official governmental channels and savings of its members.

Municipalities are affiliated with the ministry of interior in organizational terms. With respect to budget approval, however, they are under supervision of city council. In other words, municipalities act as a bridge between people and government. Income resources of municipalities include the duties of construction and renovation licenses, issuance of licenses, cooperation with private sector in the execution of projects, sale of partnership bonds, and governmental assistance. Investigation of these organizations indicates that firstly, they need a fundamental reformation in their administrative structures; secondly, their function is some cases in the scope of other organizations; and thirdly, the performance of municipalities should be supervised by supervisory institutions.

Holy shrines are religious places, the most important of which are "Astan Qods Razavi” in "Mashhad”, "Astan Moghadas” in "Qom”, “Astan Abdolazim Hasani” in "Shahr Rey”, and “Astan Shahcheraq” in "Shiraz”. “Astan Qods Razavi” has residential and agricultural lands in "Mashhad” and other cities of Iran. It is also active in the field of agriculture, industry, foodstuff and culture. Holy shrines are managed by religious characters connected with traditional market and the government. They also enjoy financial resources obtained from public contributions, economic activities and the endowed property.

\section{Inferential Analysis of Sources and Trend of Power in Iran}

Iran's economy has long faced numerous challenges such as rent, exclusiveness and oil problems. Another challenge faced by the economy is the broad economic activity of organizations which are not of an economic nature. Financial foundations influence the economy of Iran. Owing to personal and institutional linkages with the government, they have developed into the main actors of competition between groups. Financial foundations provide a framework for analyzing political, social and economic order and play a significant role in the institutionalization of ideological goals of Islamic Revolution. These foundations do activity in line with construction and competitiveness of the economy. They have an important role in economic development and redistribution of social justice. They support the gradual movement of the state towards export-oriented growth strategy and have a tendency towards foreign commerce, particularly the emerging markets in the Middle East. Owing to access to remarkable resources, they play an influential role in the society and have developed into a powerful network outside of the state.

Economic development entails the utilization of capacity of young graduates in different fields. Economy is the top priority of the country and good efforts should be made to keep class gap in a reasonable level in the economic progress. Economy is the product of collective intellect obtained from the unity of thinkers, authorities and capital elites. The achievement of this goal calls for meeting legal and executive requirements in the Legislature, the Judiciary and the Executive. Economic power sources in the country include natural resources and country economy relies on oil. The excessive presence of government in the economy has led to the reduced opportunities for public economic organizations. Oil research, exploration, exploitation and marketing are exclusive to multinational corporations. Dependence of Iran's economy on oil has led to political dependence. Today, the country has turned to tax incomes as a way of exiting from reliance on oil incomes; Exit of the government from the renter form and the creation of economic revolution. To reduce the dependence on oil incomes, necessary actions must be taken to reduce the share of oil incomes in total budget and to balance foreign trade. The reduction of reliance on oil incomes and financial clarification may be the key to the treatment of our economy. The improvement of business space through facilitation of foreign trade, privatization, and finance of 
non-governmental sector are among the important actions to be taken in line with this goal. To avoid a single-product economy and preventing its risks, mining industry needs to accompany oil industry. Moreover, the private sector capacity should be used in both industries and the sale of raw materials must be prevented. Here one can say that the nuclear industry is one of the top industries in the world and will be needed in future. While the global capitalism system has prevented developing countries from attaining nuclear energy, Iran has managed to localize nuclear energy by domestic scientists and attain nuclear knowledge and technology. As dependence on a permanent financial process, IT and advanced products is an effective way by which superpowers exert their pressures on other countries, it is necessary to boost the country in financial and technological terms.

Looking from outside has led to the opinion that the problems stem from conspiracies of western countries. Actually, however, many problems stem from bad management. In order to reach a political rationality, the society has to adopt a scientific and pluralism approach. In major decisions and planning, an emphasis should be placed on endogenous approach and necessary opportunities should be provided for foreign investment, importation of technology, and cooperation in exportation of goods using creative educated youth. This would promote business activities and enhance public support of the government. About the administrative structure of the country can be said that its efficiency has to be updated by laying down effective rules, which calls for an efficient legal supervision. There exist parallel organizations with similar duties, which reduce their effectiveness, time, and economic resources. To solve this problem, such organizations as the Legislature and the Expediency Council should adopt necessary decisions and supervise the good performance of the resolutions. Among the characteristics of the government are the passages from traditional to rational politics, having root in Iranian and Islamic culture, separation of powers, traditional and rational authority, and traditional and legal legitimacy. To advance the government programs, firstly endogenous and extroverted approaches should exist in a correlation with one other; so that internal capacities are utilized and effective synergy is made with foreign countries. Secondly, the cohesion between the government and influential groups should be enhanced, which would lead to success in both foreign and domestic policy. Thirdly, the coherence between the three powers, their obedience of the Supreme Leader, and their support of the government should be promoted, which would enhance bargaining power of the government in international domain as well as national interests. Fourthly, special attention should be paid to citizenship rights of all religions and ethnic groups. In order to attract maximum political participation, the system should develop the required mechanisms for the flexible structures, more employment of skilled forces, and activity of legal institutions such as political parties of efficient and independent press.

\section{Conclusion}

Expediency Council, Broadcasting, Islamic Revolutionary Guard's Corps, Islamic Consultative Assembly, Guardian Council, Government Cabinet, National Security Supreme Council, Islamic Council of urban and rural are the most important centers of political power in the country that are acted in order to legitimize protection and interests security of system. Cultural Revolution Supreme Council, Culture and Islamic communication organization, and seminary are the most important centers of social power in the country which are active in order to reproduce cultural influence and ideological justification of system. Islamic Revolution Guardian Corps, "Imam Khomeini” command execution headquarters, Islamic Revolution Foundation, Islamic Revolution "Mostazafan Foundation”, securities \& exchange organization, governmental banking network, Non-governmental financial organizations, social security organization, municipalities, and holy shrines are the most important centers of economic power in the country that are active in order to protect economic discipline and help the legitimacy of the system.

Clergies, families of martyrs and war veterans, NGOs are interest groups in the country that they play a role in transfer of demands to the system. The public demands from the system include freedom, development of international relations, social justice, social welfare, social security, priority of national interests over group and individual interests, domestic production, economic boom, creation of job opportunities, reduction of inflation rate, and foreign investment in political, social and economic areas. Decisions regarding foreign policy are adopted by the Supreme Leader, the executive (the President, Ministers, Ministry of Foreign Affairs, and National Security Supreme Council), the legislature, and information organizations. In foreign policy, the executive has such duties as identification, prioritization and execution of foreign interests of the country, protection of independency and territorial integrity, meeting the needs of the country, enhancement of capabilities in the said areas, and promotion of prestige of the country.

Individuals adjust their behavior based on the existing rules and relations in the country. The values stem 
from religion, dialogues and behavior of the leaders. A network of decisions, actions of leaders and executive elites are involved in the formation of values with authority. The leaders and organizations determine power trend in a society. Therefore internal support of the system calls for the efficiency of decisions adopted by managers and organizations. As the system is facing continuous demands, the behavior of leaders may vary from time to time. Moreover, there are pressures from outside environment of the system which challenge the income resources. Income resources of the country and political culture of the people are inside social factors that are important for the system. The system adjusts its behaviors in foreign politics based on its relations with global and regional powers. Since the system of Islamic Republic of Iran is a revolutionary system, it is continuously challenged by certain groups, the capitalism system and conservative governments. As a result, the decisions are sometimes strict and binding. Thanks to public support, the system of Islamic Republic of Iran is able to overcome such problems.

\section{References}

Dahl, R. A. (1957). The Concept of Power. Behavioral Science, 2, No. 3. http://dx.doi.org/10.1002/bs.3830020303

Deutsch, K. W. (1963). The Nerves of Government: Models of Political Communication and Control (pp. 243, 249). New York: Free of Glencoe.

Jantsch, E. (1972). Forecasting and Approach: A Critical Survey. Policy Sciences, 3, 482-484.

Merriam, C. E. (1966). Systematic Politics (p. 74). Chicago: University of Chicago Press.

Easton, D. (1953). The Political System: An Inquiry into the State of Political Science (p. 78). New York: Alfred A. Knopf.

Easton, D. (1957). An Approach to the Analysis of Political Systems. World Politics, 9, 389-390. http://dx.doi.org/10.2307/2008920

Easton, D. (1965). A Framework for Political Analysis (pp. 38, 57). Englewood Cliffs, New Jersey: Prentice-Hall.

Spiro, H. (1962). Comparative Politics: A Comprehensive Approach. The American Political Science Review, 56, 580. http://dx.doi.org/10.2307/1952491 